\title{
Using Geotechnology to Estimate Annual Soil Loss Rate in the Brazilian Cerrado
}

\author{
Luciene Gomes ${ }^{1}$, Silvio J. C. Simões ${ }^{2}$, Maria C. Forti' ${ }^{1}$, Jean Pierre H. B. Ometto ${ }^{1}$, Eloi L. Dalla Nora ${ }^{1}$ \\ ${ }^{1}$ Earth System Science Center (CCST), Brazilian Institute for Space Research (INPE), São José dos Campos, Brazil \\ ${ }^{2}$ Department of Environmental Engineering, Institute of Science and Technology, São Paulo State University (UNESP), \\ São José dos Campos, Brazil \\ Email: lucienegomes178@gmail.com, silvio.simoes@ict.unesp.br, cristina.forti@inpe.br, \\ jean.ometto@inpe.br, eloi.dallanora@inpe.br
}

How to cite this paper: Gomes, L., Simões, S.J.C., Forti, M.C., Ometto, J.P.H.B. and Nora, E.L.D. (2017) Using Geotechnology to Estimate Annual Soil Loss Rate in the Brazilian Cerrado. Journal of Geographic Information System, 9, 420-439.

https://doi.org/10.4236/jgis.2017.94026

Received: May 22, 2017

Accepted: July 25, 2017

Published: July 28, 2017

Copyright (C) 2017 by authors and Scientific Research Publishing Inc. This work is licensed under the Creative Commons Attribution-NonCommercial International License (CC BY-NC 4.0). http://creativecommons.org/licenses/by-nc/4.0/

\section{Open Access}

\begin{abstract}
Soil erosion is a serious environmental problem that has adversely affected the world's food production through the reduction of land productivity and water availability. The present study estimated annual soil loss rate and its spatial distribution in the most important Brazil's agricultural region, the Brazilian Cerrado, using Revised Soil Loss Equation (RUSLE) model into Geographic Information System (GIS) framework. For this purpose, the soil erosion annual rate was determined in function of RUSLE model factors: rainfall erosivity (R), soil erodibility (K), topography (LS), crop management (C) and supporting conservation practice $(\mathrm{P})$. All factors were obtained from literature. They were processed and integrated into a GIS, resulting in a map of annual soil loss rate. The methodology applied showed acceptable precision and it was possible to identify the most susceptible areas to water erosion. The average estimated rate of soil loss for the entire Cerrado was $12.8 \mathrm{t} \cdot \mathrm{ha}^{-1} \cdot \mathrm{yr}^{-1}$. Large part of the Cerrado is under low soil loss zone corresponding to $79.91 \%$ of total surface area, while $15.70 \%, 3.74 \%$, and $0.66 \%$ are under moderate, high, and very high, respectively. The average estimated rate of soil loss in areas used for silviculture was $52.1 \mathrm{t} \cdot \mathrm{ha}^{-1} \cdot \mathrm{yr}^{-1}$. In semi-perennial, perennial, and annual crops cultivation were $29.3,23.9$, and $9.8 \mathrm{t} \cdot \mathrm{ha}^{-1} \cdot \mathrm{yr}^{-1}$, respectively, while in the pasture was $13.3 \mathrm{t} \cdot \mathrm{ha}^{-1} \cdot \mathrm{yr}^{-1}$. Except for annual crops, all farm and silviculture areas showed average soil loss ranging from moderate to high rate. These results suggest that the implementation of more effective management techniques and conservation practices are necessary for the Cerrado to maintain and to improve land productivity by ensuring national and international food demands.
\end{abstract}

\section{Keywords}

Erosion, Soil Conservation, Geographic Information System (GIS), Tropical Savanna, MATOPIBA 


\section{Introduction}

Soil erosion is a serious environmental problem that has adversely affected the world food production through the reduction of land productivity and water availability [1]. Erosion is a natural geomorphic process resulting from removal topsoil by wind and water [2], and it can be influenced by several factors such as climate variables, slope steepness, soil physical parameters, vegetation and land use patterns [3]. Moreover, erosion process can be intensified by human intervention through inappropriate land use and land cover changes. In this context, severe soil erosion has occurred in the world's major agricultural regions and the problem has increased as agricultural activities intensified grown in the forest fringe areas [1].

Agricultural extensification and intensification without taking into account the bearing capacity of soils have accelerated the erosion processes in some tropical regions [4]. These areas are particularly important in the global agricultural scenario because world food projections have pointed out tropical regions as a potential source of farmland expansion to ensure food security to an additional 2.3 billion people by 2050 [5] [6] [7]. However, many of these regions have been classified as a hotspot of land degradation due to water erosion process [8].

Brazil has become the second-largest exporter of agricultural products in the world, especially due to production expansion into soils of tropical savanna also known as Cerrado [5]. In 2009-2010, the Cerrado accounted for 70\% of Brazil's food production [9] including about $95 \%$ of cotton, $54 \%$ of soybeans, $55 \%$ of meat and $43 \%$ of sugarcane produced in Brazil [10] [11]. It is the most important country's agricultural region and has been considered as one of the world's great breadbaskets [12]. However, the Cerrado is highly susceptible to water erosion due to the fragility of its landscape and its climatic characteristics [13]. Agricultural expansion may be leading severe arable land erosion causing different environmental problems and loss of biodiversity [8]. Therefore, the evaluation of soil erosion in the Cerrado needs to receive major attention since Brazil is expected contribute $40 \%$ of global food demand by 2050 [14].

However, for a successful erosion assessment inside a fragile landscape it is essential to have quantitative soil erosion data and its spatial distribution. From these data, it is possible to design and implement appropriate erosion control where conservation measures will have a great impact on reduction of soil loss and water conservation [15]. There are different methods to assess quantitative soil erosion [16]. Universal Soil Loss Equation (USLE) [17] and Revised Universal Soil Loss Equation (RUSLE) [18] are the most frequently used. Advantages of these methods are simplicity, effectiveness of the equations, and success in predicting long term average annual soil loss with acceptable accuracy [19].

These models were originally used for local conservation planning and their factors were usually estimated or calculated from field measurements [17]. Quantifying soil loss based on erosion plots cannot provide the spatial distribution of soil erosion in large and difficult access areas, as in several regions of 
Brazil, due to limitations in terms of cost, representativeness, and reliability of the results data [20] [21]. However, when assessment of soil erosion is integrated with a Geographical Information System (GIS) environment is possible to estimate soil erosion and its spatial distribution with a reasonable time, cost, and labor reduction and to improve accuracy in large areas [20]. This integration has been widely used, especially in developing countries, such as Brazil, India, and Turkey [20] [21] [22] [23] [24]. Thus, the main objective of the study is to estimate the spatial distribution of annual soil loss rate using RUSLE model integrated into a GIS, and investigate the relationship between farmland and forestry uses with soil loss for Brazilian Cerrado, the most important agriculture region in Brazil. In general, studies estimate annual soil loss rate in small regions [22] [25] [26]. Here, we present a spatial distribution of annual soil loss rate for the entire Brazilian Cerrado.

\section{Materials and Methods}

\subsection{Study Area}

Brazilian Cerrado (Figure 1) is one of the richest and most diverse tropical savanna in the world [27] covering approximately 2 million $\mathrm{km}^{2}$ of the Brazilian Central Plateau (24\% of the whole area of the country). The region has a markedly tropical wet and dry seasons with annual precipitation varying from 800 to $1800 \mathrm{~mm}$ [28]. The average annual temperature varies from $20^{\circ} \mathrm{C}$ to $26^{\circ} \mathrm{C}$ [29]. Predominant soil types in the Cerrado area are Ferralsols $(\sim 41 \%)$, Arenosols ( 15\%), Acrisols ( 12\%), and Plinthosols ( 10\%) [30] based on the FAO classification [31]. The region is relatively flat with low relief and flat to gentle slopes. [32]. The four main vegetation types are grassland (campo limpo), grassland
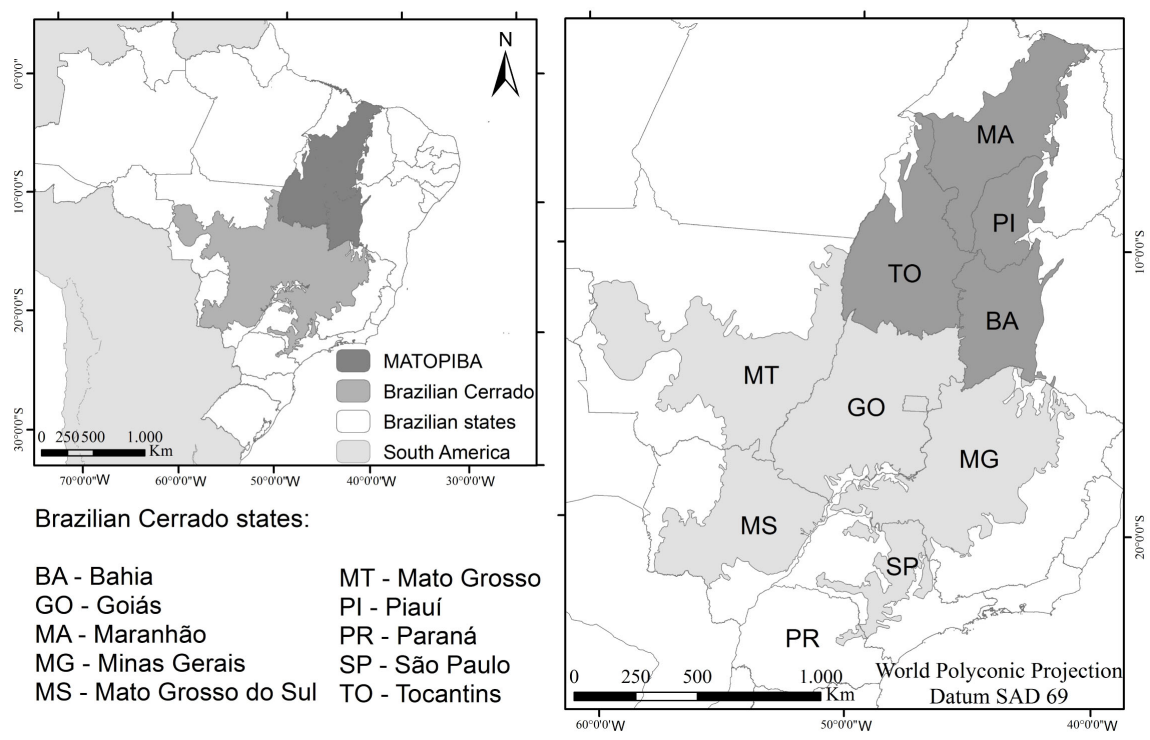

Figure 1. Location of the study area. Brazilian Cerrado encompasses totally or partially the states of Bahia (BA), Goiás (GO), Maranhão (MA), Minas Gerais (MG), Mato Grosso do Sul (MS), Mato Grosso (MT), Piauí (PI), Paraná (PR), São Paulo (SP) and Tocantins (TO). 
with scattered trees (campo sujo), savannah (cerrado in the strict sense), and woodland (cerradão) [28] [33]. The Cerrado region is considered as one of the most important and threatened ecosystems in the world [34] due to agricultural extensification and corresponds to a land degradation hotspot where large areas are being affected by erosion process [8]. In addition, the Cerrado region is home of the Brazil's new agriculture frontier, commonly called "MATOPIBA" which is an acronym created from the first two letters of the four Brazilian states: Maranhão (MA), Tocantins (TO), Piauí (PI) and Bahia (BA). This region has been characterized by rapid changes in land cover and land use for pasture and cropland [35].

\subsection{Data Acquisition and Processing}

In this study, all input data for the RUSLE model were stored, analyzed, and visualized within the ArcGIS environment (version 10.3). The GIS database were georeferenced using World Polyconic projection and SAD 69 (South American Datum 1969). The full database (vector and raster formats) includes the following:

1) Erosivity Map (approximated scale of $1: 5,000,000$ ) obtained from [36];

2) Soil Map from EMBRAPA (Brazilian Agriculture Research Corporation) at the scale 1:5,000,000 [30];

3) Digital Elevation Model (DEM) generated from TOPODATA database provided by INPE (Brazilian Institute for Space Research) with spatial resolution of $30 \mathrm{~m}$ from SRTM data produced by NASA originally [32];

4) 2010 Land Use and Cover Map produced by IBGE (Brazilian Institute for Geography and Statistics) at the scale 1:5,000,000 [37]. This map has fourteen different land use and land cover units, which were reclassified in order to represent the classes of interest as follows:

a) Agriculture class-agriculture areas, mosaic of agricultural areas with remaining forest, mosaic of forest vegetation with agricultural areas, and mosaic of grassland with agricultural areas;

b) Pasture-planted and managed pastureland (e.g. cattle-ranching);

c) Silviculture-planted and managed forests with exotic species (e.g. eucalyptus, pines);

d) Natural vegetation-includes natural vegetation in different stages of ecological succession (e.g. forest vegetation, grassland, wetland);

e) Others-artificial areas (e.g. urbanized zones, road systems, non-agricultural systems), continental water bodies, coastal water bodies, and uncovered lands (e.g. rocks outcrops and sand dunes).

The Agriculture unit was split over into three classes aiming to separate agricultural areas from forest vegetation and grassland: annual (grains), semi-perennial (sugarcane), and perennial (coffee and citrus). For that, Agriculture unit was multiplied by spatially explicit data of grains [38], sugarcane [39], coffee [40] and citrus [40]. As a result, it was obtained Annual, Semi-perennial and Perennial agricultural units while residues were reclassified as Natural vegetation. 
Therefore, the resulting map comprises seven land-use units: Pasture, Natural vegetation, Forestry, Annual crops, Semi-perennial crops, Perennial crops and Others.

\section{Methods}

\subsection{RUSLE Model}

Estimation of soil loss and its spatial distribution were obtained using RUSLE model integrated into a GIS. RUSLE is an empirical mathematical model developed to estimate soil erosion water [18]. The evolution and the improvement over the USLE lead to the RUSLE computer program. In the same way as its predecessor, the model does not estimate sediment deposition on the slope [41], but only establishes an estimate of the average annual soil loss caused by rill and interril erosion [42]. As a result, the RUSLE model estimates the potential soil loss rates, which indicate the intensity of the erosion processes. The model is a product of five factors, according to Equation (1):

$$
A=R \times K \times L S \times C \times P
$$

where $A$ is the annual average soil loss per unit of area $\left(\mathrm{t} \cdot \mathrm{ha}^{-1} \cdot \mathrm{yr}^{-1}\right), R$ is the rainfall-runoff erosivity factor (MJ.mm $\left.\cdot \mathrm{ha}^{-1} \cdot \mathrm{h}^{-1} \cdot \mathrm{yr}^{-1}\right), K$ is the soil erodibility factor $\left(\mathrm{t} \cdot \mathrm{h} \cdot \mathrm{MJ}^{-1} \cdot \mathrm{mm}^{-1}\right), L S$ is the slope length and slope steepness factor (dimensionless), $C$ is the crop management factor (dimensionless), and $P$ is the erosion control practice factor (dimensionless). Integrated into a GIS, soil erosion loss was calculated on a cell-by-cell basis in order to recognize the spatial patterns of soil loss. Thus, each factor was calculated taking grid cells of $2822 \mathrm{~m} \times 2822 \mathrm{~m}$ as reference and an uniform spatial analysis environment for GIS modeling was established [22]. In general, grid cells should be as small as possible to allow erosion to be characterized with a better resolution [22]. However, in this study, we had to use a $2822 \mathrm{~m}$ spatial resolution for all factors considered because no references about R-factor was found with better resolution than $2822 \mathrm{~m}$ for the study area. Spatial distribution of soil erosion loss was produced multiplying all factor layers to produce a final map. The methodological approach followed in RUSLE has been detailed in the simplified flowchart depicted in Figure 2.

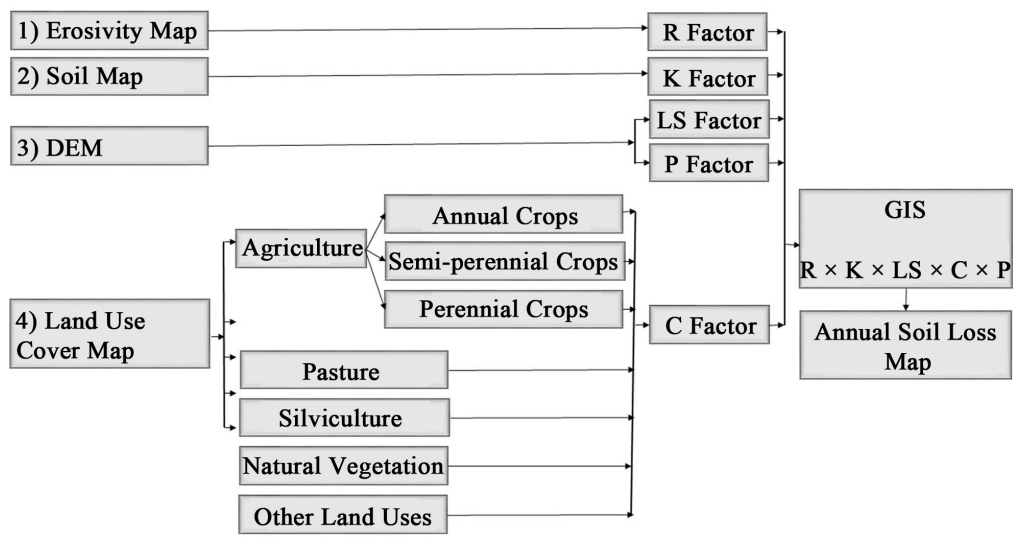

Figure 2. Flowchart of the methodology to estimate averaged rate of soil loss and its spatial distribution for Brazilian Cerrado using RUSLE model integrated into a GIS. 


\subsection{Rainfall-Runoff Erosivity Factor $(R)$}

Erosivity factor $(R)$ represents the erosive power of precipitation in a given soil, regolith or other weathered material. Precipitation is the driving force of erosion and has a direct effect on different phases of the erosional processes including the detachment of soils particles, the breakdown of aggregates and the transport of eroded material by runoff. The R-factor is the kinetic energy of raindrops that fall onto the ground and is affected by rainfall intensity and raindrop size [17]. Figure 3 shows rainfall-runoff erosivity factor map.

\subsection{Erodibility Factor $(K)$}

The soil erodibility factor $(K)$ is a property that depends upon two factors; the first one is the infiltration capacity to resist the detachment and transportation by rainfall and the second one is the runoff process [43]. Therefore, $K$ values reflect the rate of soil loss per rainfall-runnoff erosivity $(R)$ index for a specific soil [18]. The K-factor varies from zero to one, in which zero refers to soils with less susceptibility to water erosion while one refers to soils higher susceptible [44]. The K-factor map was produced based on soil map and erodibility values published from several studies conducted in different areas of Brazil for the same soil types. The $\mathrm{K}$ values for each soil type of Brazilian Cerrado can be observed in Table 1.

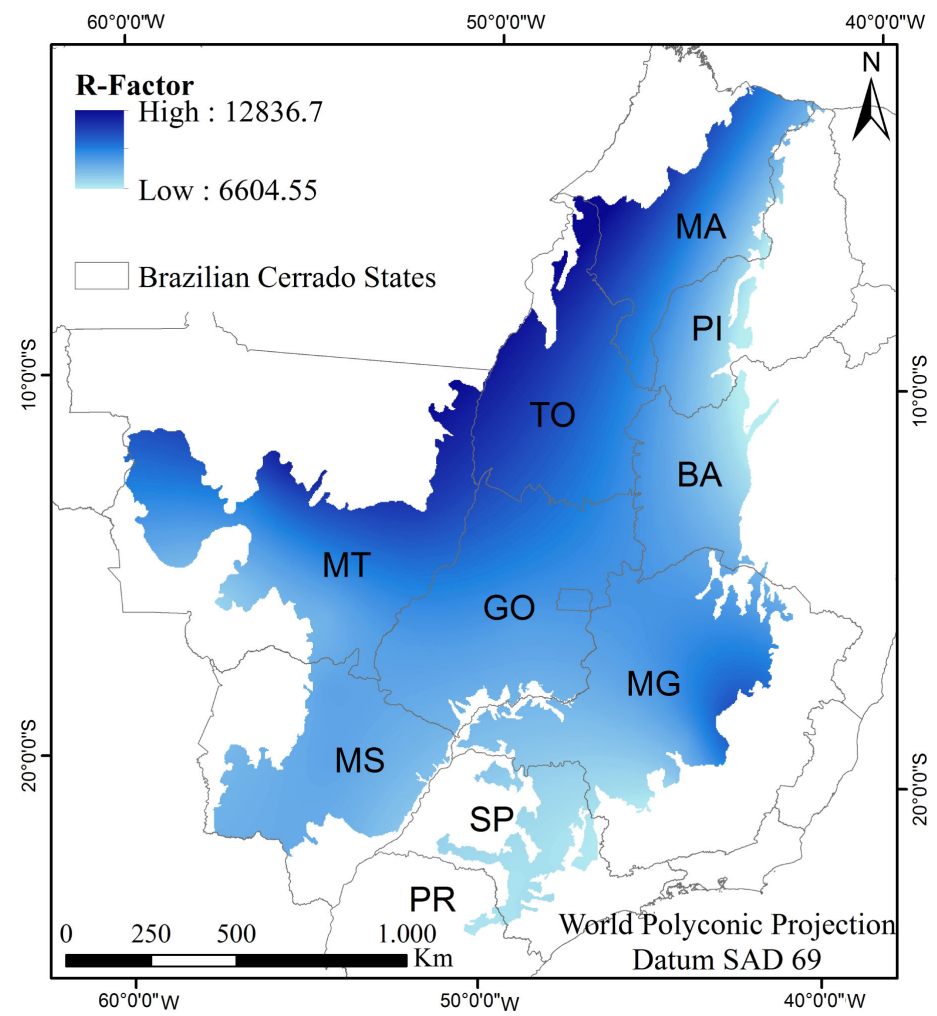

Figure 3. Rainfall-runoff erosivity factor (R) map of the study area [36]. Brazilian Cerrado states are: Bahia (BA), Goiás (GO), Maranhão (MA), Minas Gerais (MG), Mato Grosso do Sul (MS), Mato Grosso (MT), Piauí (PI), Paraná (PR), São Paulo (SP) and Tocantins (TO). 
Table 1. Soil classification on the Brazilian Cerrado and soil erodibility (K) values and their respectives sources.

\begin{tabular}{|c|c|c|c|c|c|}
\hline No. & Brazilian Classification & FAO Classification & Area (\%) & $\mathrm{K}\left(\mathrm{t} \cdot \mathrm{h} \cdot \mathrm{MJ}^{-1} \cdot \mathrm{mm}^{-1}\right)$ & Source \\
\hline 1 & Latosol & Ferralsols & 40.61 & $0.010-0.028$ & $\begin{array}{l}{[25][45]} \\
{[46][47]}\end{array}$ \\
\hline 2 & Quartzarenic Neosols & Arenosols & 14.38 & $0.046-0.056$ & [25] [48] \\
\hline 3 & Argisols & Acrisols & 11.90 & $0.031-0.055$ & $\begin{array}{c}{[25][45]} \\
{[48]}\end{array}$ \\
\hline 4 & Plinthosols & Plintosols & 10.21 & $0.012-0.055$ & [25] [47] \\
\hline 5 & Cambisols & Cambisols & 9.37 & $0.036-0.043$ & $\begin{array}{c}{[25][46]} \\
{[49]}\end{array}$ \\
\hline 6 & Litholic Neosols & Leptosols & 8.03 & $0.036-0.050$ & [25] [47] \\
\hline 7 & Gleysols & Gleysols & 1.63 & 0.001 & [47] \\
\hline 8 & Planosols & Haplics & 0.80 & 0.057 & [25] \\
\hline 9 & Regolithic Neosols & Regosols & 0.61 & 0.050 & [47] \\
\hline 10 & Chernosols & Chernozems & 0.58 & 0.030 & [50] \\
\hline 11 & FluvicNeosols & Fluvisols & 0.56 & 0.046 & [47] \\
\hline 12 & Luvisols & Luvisols & 0.40 & 0.150 & {$[46]$} \\
\hline 13 & Nitosols & Nitisols & 0.27 & 0.011 & {$[25]$} \\
\hline 14 & Vertisols & Vertisols & 0.08 & 0.040 & {$[51]$} \\
\hline 15 & Organosols & Histosols & 0.01 & 0.061 & [50] \\
\hline 16 & Others $^{\mathrm{a}}$ & Others & 0.56 & - & - \\
\hline
\end{tabular}

${ }^{\mathrm{a}}$ Water, rocks, and dunes.

\subsection{Topographic Factor $(L S)$}

The topographic factor represents the influence of the relief on the erosion process [18]. The LS-factor depends on the slope steepness $(S)$ and slope length $(L)$ factors considering slopes as uniform profiles. In general, soil erosion increases as the slope steepness increases due to increased runoff flow velocity. As well as, soil erosion increases as slope length increases because of rising accumulation of runoff in down slope [17] [44]. Maximum slope length are seldom longer than $600 \mathrm{ft}$ or shorter than $15-20 \mathrm{ft}$ [52]. Both are obtained from Digital Elevation Model (DEM) considering different approaches and methods [22] [53]. This study was based on [53] that calculated L-factor using as reference the upslope contributing area of each cell according to Equation (2):

$$
L_{i, j}=\frac{\left[\left(A_{i, j-i n}+D^{2}\right)^{m+1}-\left(A_{i, j-i n}\right)^{m+1}\right]}{\left[D^{m+2} \times x_{i, j}^{m} \times(22.13)^{m}\right]}
$$

where $L_{i, j}$ is the slope length factor for grid cell with coordinates $\left({ }_{\mathrm{i}, \mathrm{j}}\right) . A_{i, j-i n}$ is the contributing area at the inlet of grid cell with coordinates $\left({ }_{\mathrm{i}, \mathrm{j}}\right)\left(\mathrm{m}^{2}\right) ; D$ is the grid cell size $(\mathrm{m}) ; m$ is a dimensionless exponent that depends on slope steepness $(S)$; $x_{i, j}$ is flow direction value for the grid cell with coordinate $\left({ }_{i, j}\right)$. The exponent $m$ 
was calculated according to [17] being $S<1 \%, m=0.2 ; 1 \% \leq S \leq 3 \%, m=0.3$; $3 \%<S \leq 5 \%, m=0.4$; and $S>5 \%, m=0.5$.

The $S$ factor was calculated based on [54], according to Equations (3) and (4):

$$
\begin{aligned}
& S=10.8 \times \sin \theta+0.03 \text { for slopes }<9 \% \\
& S=16.8 \times \sin \theta-0.50 \text { for slopes } \geq 9 \%
\end{aligned}
$$

where $\theta$ is the slope angle $\left({ }^{\circ}\right)$. Slope steepness was divided into six categories based on [55] as depicted in Table 2.

\subsection{Cover and Management Factor (C)}

The cover and management factor $(\mathrm{C})$ represents an integration of several factors that affect erosion, including vegetative cover, plant litter, soil surface and land management [17] [18] [52]. This is the second most important factor in RUSLE, only after topography, since it represents the conditions that can be easily changed to reduce overland flow and soil erosion [22] [44]. Although treated as an independent variable in the equation, this factor depends upon other factors. The C-factor varies from near zero (for a good erosion protection) to one (for a poor erosion protection) [56]. As mentioned before, in this work was considered seven land use classes for Brazilian Cerrado: Pasture, Natural vegetation, Silviculture, Annual crops, Semi-perennial crops, Perennial crops and Others. The C-factor values extracted from literature and percentage of the area to each land use are presented in Table 3.

Table 2. Slope steepness categories for Brazilian Cerrado by [55].

\begin{tabular}{ccc}
\hline Categories (\%) & Relief Classification & Area (\%) \\
\hline $0-3$ & Flat Reliefs & 89.98 \\
$3-8$ & Gentle Hillslope & 8.88 \\
$8-13$ & Moderate to Gentle Hillslope & 0.99 \\
$13-20$ & Strongly Undulating Relief & 0.14 \\
$20-45$ & Mountain with Steep Hillslope & 0.01 \\
$45-100$ & Ridge Escarpments & 0.00 \\
\hline
\end{tabular}

Table 3. Values of the cover management factor (C) for each land use cover class of the Brazilian Cerrado.

\begin{tabular}{ccccc}
\hline No. & Land use & Area (\%) & C & Source \\
\hline 1 & Pasture & 41.20 & 0.05 & {$[57][58]$} \\
2 & Natural Vegetation & 47.84 & 0.01 & {$[59]$} \\
3 & Silviculture & 0.92 & 0.30 & {$[60]$} \\
4 & Annual crops & 6.73 & 0.08 & {$[61]$} \\
5 & Semi-perennial crops & 1.72 & 0.31 & {$[62]$} \\
7 & Perennial crops & 0.43 & 0.11 & {$[63]$} \\
\hline
\end{tabular}




\subsection{Supporting Practice Factor (P)}

The effect of erosion control practice (P) represents the relationship between soil loss with a specific support practice and the corresponding loss with up-down slope cultivation [64]. P-factor varies according to soil conservation practices and, thus, it has a strong influence on soil loss [22]. Practices characterized by $P$ include strip-cropping and terraces and are not applicable to most forested region. Since the soil conservation practices for each system cannot be known for entire Brazilian Cerrado, where about $880,000 \mathrm{~km}^{2}$ are occupied by farmlands, the values for P-factor were determined according to [65] that calculated this factor based on slope angle ( $\alpha$ ). Thus, the $P$ was 0.6 for $0 \leq \alpha \leq 5 \%, 0.69947-$ $0.08991 \alpha+0.01184 \alpha^{2}-0.00035 \alpha^{3}$ for $5 \%<\alpha \leq 20 \%$ and 1.0 for $\alpha>20 \%$.

\section{Results and Discussion}

The spatial distribution of all RUSLE's factor (K, C, LS and P) can be observed in the Figures 4-7, respectively. The variety of soil types produced a large spatial variability (Figure 4 ) where $56.35 \%$ of total area has $\mathrm{K}$-factor higher than 0.03 $\mathrm{t} \cdot \mathrm{h} \cdot \mathrm{MJ}^{-1} \cdot \mathrm{mm}^{-1}$ (Table 1$)$. These results indicates that more than half of the soils in the Cerrado show high susceptibility to water erosion [22]. Arenosols, Acrisols, Plintosols, Cambisols and Leptosols represent soils with higher potential for erosion with large amount of particles (sand and silt) that are easily detached and carried away. One the other hand, soils with low susceptibility comprises

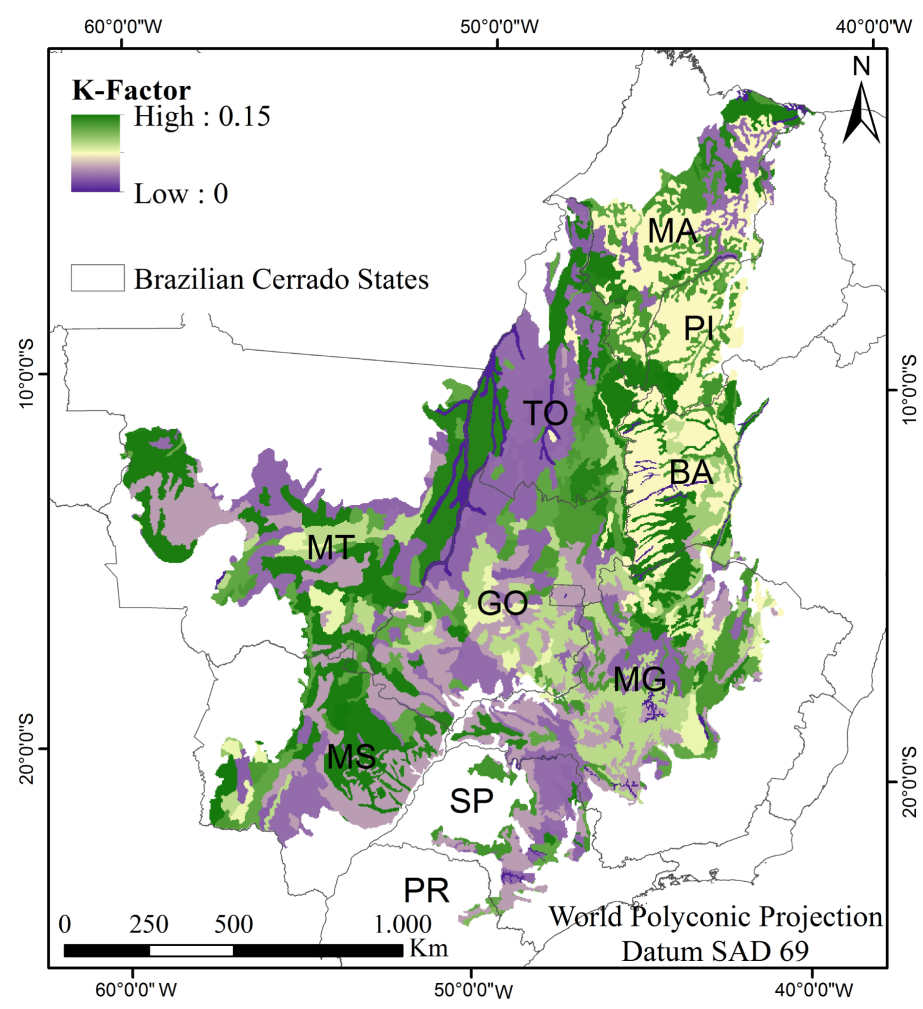

Figure 4. Soil erodibility factor (K) map of the study area. Brazilian Cerrado states are: Bahia (BA), Goiás (GO), Maranhão (MA), Minas Gerais (MG), Mato Grosso do Sul (MS), Mato Grosso (MT), Piauí (PI), Paraná (PR), São Paulo (SP) and Tocantins (TO). 


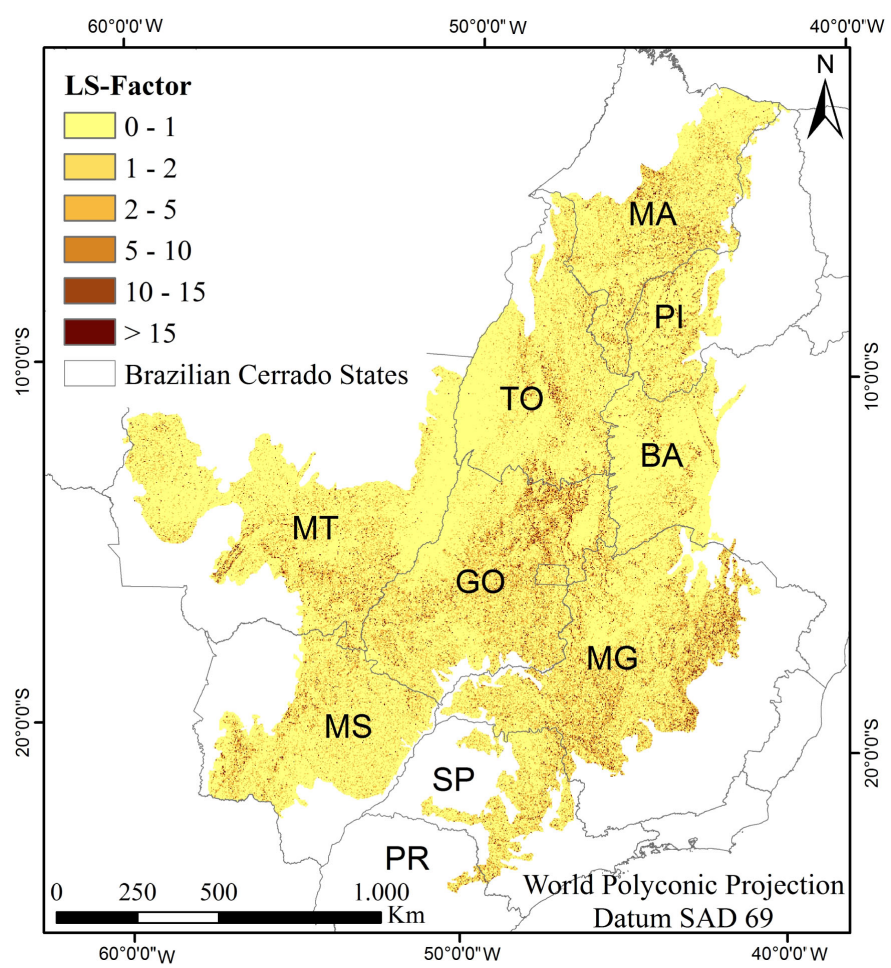

Figure 5. Soil topographic factor (LS) map of the study area. Brazilian Cerrado states are: Bahia (BA), Goiás (GO), Maranhão (MA), Minas Gerais (MG), Mato Grosso do Sul (MS), Mato Grosso (MT), Piauí (PI), Paraná (PR), São Paulo (SP) and Tocantins (TO).

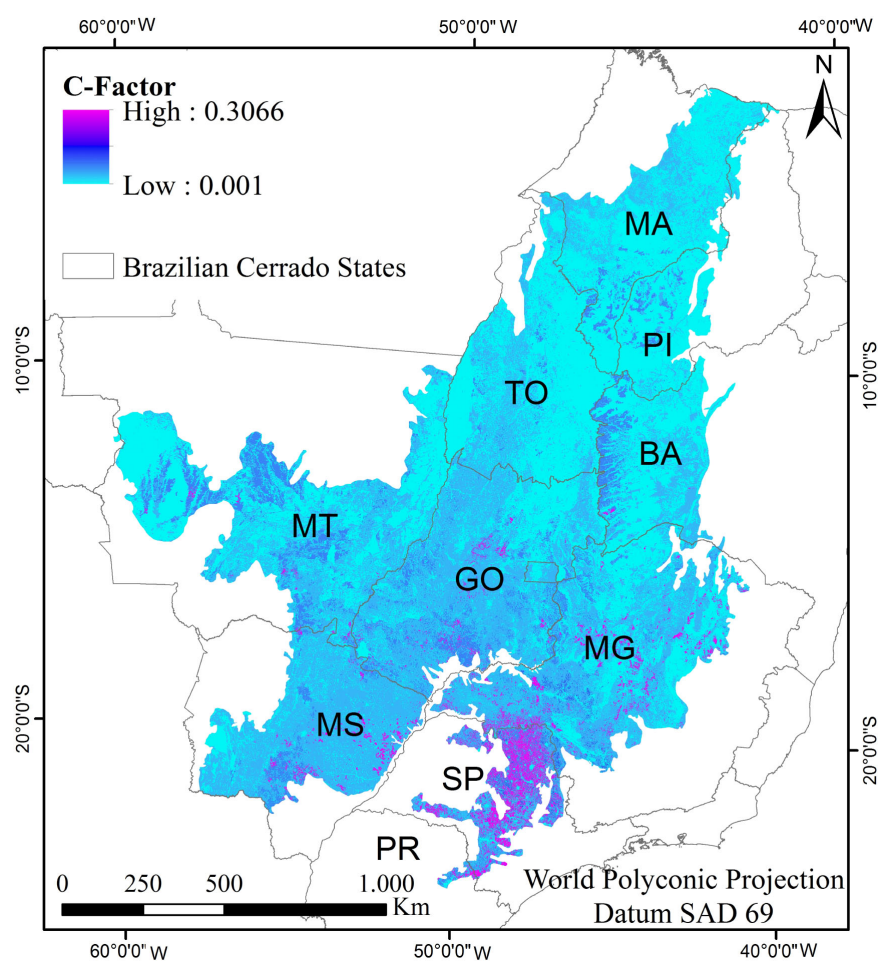

Figure 6. Soil cover and management factor (C) map of the study area. Brazilian Cerrado states are: Bahia (BA), Goiás (GO), Maranhão (MA), Minas Gerais (MG), Mato Grosso do Sul (MS), Mato Grosso (MT), Piauí (PI), Paraná (PR), São Paulo (SP) and Tocantins (TO). 


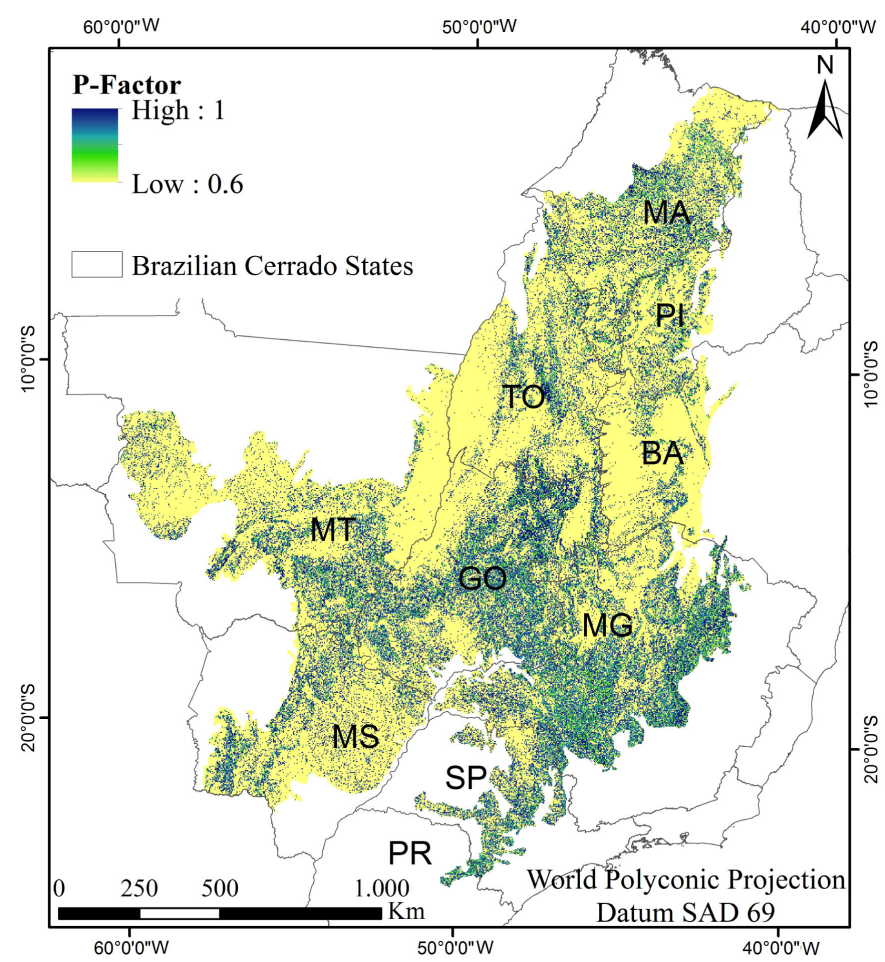

Figure 7. Soil supporting practice factor (P) map of the study area. Brazilian Cerrado states are: Bahia (BA), Goiás (GO), Maranhão (MA), Minas Gerais (MG), Mato Grosso do Sul (MS), Mato Grosso (MT), Piauí (PI), Paraná (PR), São Paulo (SP) and Tocantins (TO).

43.09\% of total area. These soils are represented by Ferralsols, Gleysols, Chernosols and Nitisols which have lower erodibility due to higher relative content of clay and organic matter. Despite of large spatial variability of K-factor, it is possible to observe where the more susceptible areas to very rate erosion are concentrated. They comprise the Maranhão (MA), Piauí (PI), Bahia (BA) and part of Tocantins (TO) states (Figure 3 ). The soil erosion fragility in these parts of Cerrado shows how important are the effective land management practices. This is a very important point because the Brazilian's largest changes in land-use and land-cover have been occurring exactly in this region (MATOPIBA) where soils prone to higher erosion rates are predominant.

LS-factor is very important in RUSLE since the topography affects the runoff characteristics and sediment transport [64]. The Table 4 presents the area distribution of each LS-factor intervals. About $93 \%$ of total area of Cerrado has a LS values above 5, which refers to moderate vulnerability to water erosion [22], while only $2.69 \%$ of its total area has LS-factor greater than 10, indicating high vulnerability to water erosion [22]. Figure 5 shows spatial distribution of LS-factor; the highest values are concentrated in regions with undulating and strongly undulating topography where runoff flow velocity are higher, especially in the Goiás (GO), Minas Gerais (MG), and Mato Grosso (MT) states.

The C-factor corresponding to Crop/Vegetation and Management Factor ranged from 0.001 to 0.3066 (Figure 6). As mentioned before, values closer to 
Table 4. Categories of topographic factor (LS) for the Brazilian Cerrado.

\begin{tabular}{ccc}
\hline No. & Categories & Area (\%) \\
\hline 1 & $0-1$ & 69.73 \\
2 & $1-2$ & 13.14 \\
3 & $2-5$ & 10.49 \\
4 & $5-10$ & 3.95 \\
5 & $10-15$ & 1.21 \\
6 & $>15$ & 1.48 \\
\hline
\end{tabular}

zero are indicates of very good protected soils; in contrast, values closer to one indicate very poor protection [53]. The highest C-factor values $(\sim 0.30)$ for Brazilian Cerrado were associated to semi-perennial crops and silviculture. These systems are located especially in the states of São Paulo (SP), Minas Gerais (MG), Mato Grosso do Sul (MS) and Goiás (GO) (Figure 6). Areas with C-factor of 0.10 are also found in Minas Gerais and São Paulo occupied by perennial crops. In general, conventional tillage, with plowing and disking, is adopted in most of agricultural systems in Brazil, which favors the erosion processes [66]. In many silviculture systems, conventional tillage also is employed [60]. In addition, depending on the silviculture development phase, soil cover varies from zero to ninety percent. C-factor values of 0.90 are attributed to planting phase ( $0 \%$ of cover soil), 0.28 to intermediate phase ( $60 \%$ of cover soil), and 0.05 to final phase (90\% of cover soil) [67]. Taking into account that silviculture development phase cannot be known for the entire Brazilian Cerrado area, we adopted C-factor of 0.30 . Annual crops have a lower C-factor value (0.08) because more than $50 \%$ of its area is managed using conservation tillage practices, which significantly decreases soil losses [68]. With regard to pasture, it was estimated, from experimental data, C-factor values of 0.061 and 0.007 for highly degraded and not degraded pastures respectively for Cerrado [57]. Considering that approximately $80 \%$ of pasture in Cerrado has already some degree of degradation [58], we adopted a C-factor value of 0.05 for all pasture area. Vast areas with $\mathrm{C}$-factor between 0.08 and 0.05 are located in practically all states covered by the Cerrado (Figure 6). Natural vegetation has the lowest C-factor values indicating very good soil protection; most of these lands are in the MATOPIBA region which is situated in North of Cerrado biome.

The P-factor varies according to soil conservation practices. In this study $\mathrm{P}$-factor was based on slope values to define conservation practices and the values varied from 0.6 to 1 (Figure 7). Values closer to 0.6 indicates most efficient conservation practices, while values closer to 1 indicates less appropriate conservation practices. In general, P-factor was closer to 1 in most steep areas (undulating and strongly undulating relief).

Revised Universal Soil Loss Equation was originally used for estimating average annual soil loss based on sample plot data [17] [20]. However, RUSLE and GIS integration allowed quantifying soil loss rates in a spatially explicit approach 
producing interpretative maps and a final map of average annual soil loss for Brazilian Cerrado, based on 2010 land-use map. The use of GIS allowed managing and analyzing data from different formats, qualities, projections and spatial resolutions. However, uncertainties about data sources can be introduced in soil erosion estimates, and combined with low resolution dataset, can make difficult to get better erosion estimates. A $2822 \mathrm{~m}$-resolution was used to calculate all RUSLE factors, which may underestimate the values of these parameters. Therefore, data with better resolutions would be preferable if were available. Unfortunately in Brazil, high resolution R-factor for large areas are scarce; this type of resolution is only available in smaller areas.

In summary, this study provides a potential estimate of soil loss in the Brazilian Cerrado based on the combination of RUSLE and GIS, and these results can provide support to establish environmental conservation plan where crop farms and silviculture operations may become active agents of soil erosion.

In general, the average estimated rate of soil loss for the Cerrado was 12.8 $\mathrm{t} \cdot \mathrm{ha} \mathrm{a}^{-1} \cdot \mathrm{yr}^{-1}$, which may be considered as moderate soil loss [69]. The values estimated in our analyses are consistent with those observed by [26], who estimated average rate of soil loss rate of $12.5 \mathrm{t} \cdot \mathrm{ha}^{-1} \cdot \mathrm{yr}^{-1}$ for a watershed with different land uses (crops, pasture, and natural vegetation) within the Cerrado region. Figure 8 shows the Map of Average Soil Loss, considering 2010 as reference year, which identifies the most vulnerable areas to high rates of soil erosion. These areas occur mainly in São Paulo (SP), Minas Gerais (MG), Goiás (GO), Mato Grosso do Sul (MS) and Mato Grosso (MT) states. As expected, the areas with very high

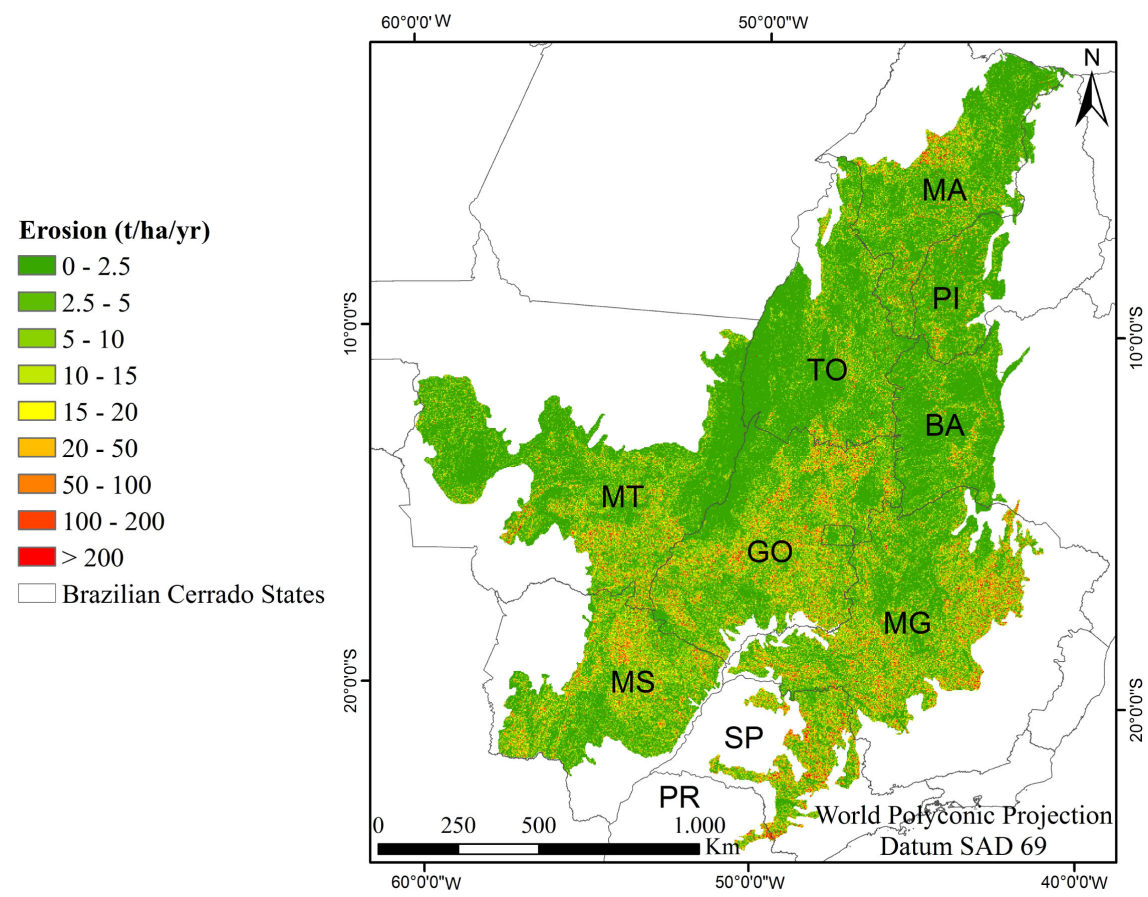

Figure 8. Map of average soil loss in 2010 of the study area. Brazilian Cerrado states are: Bahia (BA), Goiás (GO), Maranhão (MA), Minas Gerais (MG), Mato Grosso do Sul (MS), Mato Grosso (MT), Piauí (PI), Paraná (PR), São Paulo (SP) and Tocantins (TO). 
annual soil loss ( $\left.>50 \mathrm{t} \cdot \mathrm{ha}^{-1} \cdot \mathrm{yr}^{-1}\right)$ are concentrated in regions with steep slopes and some regions with predominance of pasture, crops, and forestry.

Table 5 shows the spatial distribution of different erosion classes. The major part of the Cerradois formed by soils with reduced erosion loss zone covering large areas $(47.84 \%)$. It is especially associated with natural vegetation, which provides good soil protection, and low LS-factor (69.73\%) related to flat and gently undulating relief. Respectively, $15.7 \%$ and $3.74 \%$ of Cerrado area can be considered as under moderate soil loss zone and high soil loss zone. The latter one are in areas where steeper slopes occur. In addition, it can be observed a significant soil loss associated with farm and silviculture land. The most critical land use and land covers units are silviculture and semi-perennial and perennial crops, that combined with the practice of conventional tillage allowed soils with very high losses. In quantitative terms, the average soil loss rate was 52.1, 29.3, $23.9 \mathrm{t} \cdot \mathrm{ha}^{-1} \cdot \mathrm{yr}^{-1}$ for forestry, semi-perennial, and perennial crops, respectively. The lowest values were obtained for annual crops with $9.8 \mathrm{t} \cdot \mathrm{ha}^{-1} \cdot \mathrm{yr}^{-1}$ mainly due to no tillage practice, followed by pasture with $13.3 \mathrm{t} \cdot \mathrm{ha}^{-1} \cdot \mathrm{yr}^{-1}$. The Table 6 shows comparative soil loss values obtained from this study and other studies performed in the different regions in Brazilian Cerrado. Soil loss values variation can be attributed to methodological differences with regard to how the models factor were obtained and the difference between $\mathrm{C}$-factor adopted for each category of land use.

Table 5. Interval of the soil losses estimated for Brazilian Cerrado in 2010, according to [69].

\begin{tabular}{ccc}
\hline Soil loss zone & Soil loss interval $\left(\mathrm{t} \cdot \mathrm{ha}^{-1} \cdot \mathrm{yr}^{-1}\right)$ & Area (\%) \\
\hline \multirow{2}{*}{ Low } & $0-2.5$ & 52.74 \\
& $2.5-5$ & 14.93 \\
& $5-10$ & 12.24 \\
Moderate & $10-15$ & 5.48 \\
& $15-20$ & 3.25 \\
High & $20-50$ & 6.97 \\
Very high & $50-100$ & 2.60 \\
& $100-200$ & 1.14 \\
\hline
\end{tabular}

Table 6. Comparative soil loss values from this study and other studies performed in the Brazilian Cerrado regions.

\begin{tabular}{ccc}
\hline Land use & $\begin{array}{c}\text { Soil loss from this } \\
\text { study }\left(\mathrm{t} \cdot \mathrm{ha}^{-1} \cdot \mathrm{yr}^{-1}\right)\end{array}$ & $\begin{array}{c}\text { Soil loss from other } \\
\text { studies }\left(\mathrm{t} \cdot \mathrm{ha}^{-1} \cdot \mathrm{yr}^{-1}\right)\end{array}$ \\
\hline Forestry & 52.1 & $30.7[70]$ \\
Semi-perennial crops & 29.3 & $30.0[71]$ \\
Perennial crops & 23.9 & $9.3[70]$ \\
Pasture & 13.3 & $11.2[70]$ \\
Annual crops & 9.8 & $2.5[72]$ \\
\hline
\end{tabular}


These results can guide regional planning for soil conservation and environmental management, as well as, in the selection of control practices that are the best suit to each land use systems. With the exception of annual crops areas, all farm areas and silviculture land showed average soil loss ranging from moderate to high values. Moreover, agricultural expansion at expenses of natural vegetation and agricultural intensification towards soils more fragile can lead to the increase of soil erosion loss in the Brazilian Cerrado significantly over time, since large part of the soils are highly susceptive to erosion. This is most prominent in the North region corresponding to MATOPIBA where deforestation rates have been very high and soil are highly sandy and with high erosion potential [73].

\section{Conclusions}

The methodology applied for estimating annual soil loss and its spatial distribution (RUSLE integrated into GIS framework) in the Brazilian Cerrado, showed a good precision and it was possible to identify the most susceptible areas to water erosion. It provides support to define recovery and conservation plans where agriculture and silviculture may become agents of soil erosion. Despite the good results obtained, a spatial resolution of 2822 meters used in this study can underestimates soil loss particularly in areas where gully erosions is dominant. Unfortunately input data with better resolutions are not available for large areas in the Brazilian territory particularly related to the soil erosivity.

The average estimated rate of soil loss was moderate with $12.8 \mathrm{t} \cdot \mathrm{ha}^{-1} \cdot \mathrm{yr}^{-1}$ considering the total Cerrado area. Areas most vulnerable to erosion are especially in steeper slope areas combined with pasture, crops, and silviculture land uses. Large part of the total Cerrado area is under low soil loss zone which corresponds to $79.91 \%$, while $15.70 \%, 3.74 \%$, and $0.66 \%$ are under moderate, high, and very high soil loss zones, respectively.

The average estimated rate of soil loss in areas with silviculture operation was $52.1 \mathrm{t} \cdot \mathrm{ha}^{-1} \cdot \mathrm{yr}^{-1}$. In areas with predominance of semi-perennial, perennial, and annual crops cultivation the values obtained were $29.3,23.9$, and $9.8 \mathrm{t} \cdot \mathrm{ha}^{-1} \cdot \mathrm{yr}^{-1}$, respectively, while in the pasture was $13.3 \mathrm{t} \cdot \mathrm{ha}^{-1} \cdot \mathrm{yr}^{-1}$. Except for annual crops, all farm and silviculture areas showed average soil loss ranging from moderate to high rate. Therefore, good crop management practices in regions with fragile soils, such as no-tillage, terrace, green fertilizers, and avoid removing the litter layer of the soil cover, are important factors to reduce soil loss process in the Brazilian Cerrado and to maintain and to improve land productivity by ensuring national and international food demands.

\section{Acknowledgements}

The authors would like to thank CAPES (Coordination for the Improvement for Higher Education Personnel) for Luciene Gomes scholarship. One of authors would like to thank the participation in the project "Nitrogen Cycling in Latin America: Drivers, Impacts and Vulnerabilities project (CRN3005)" and the 
Earth System Science Center (CCST), National Institute for Space Research (INPE) for the graduate opportunity.

\section{References}

[1] Pimentel, D., Allen, J., Beers, A., Guinand, L., Linder, R., McLaughlin, P., Meer, B., Musonda, D., Perdue, D., Poisson, S., Siebert, S., Sotner, K., Salazar, R. and Hawkins, A. (1987) World Agriculture and Soil Erosion. BioScience, 37, 277-283. https://doi.org/10.2307/1310591

[2] Gares, P.A., Sherman, D.J. and Nordstrom, K.F. (1994) Geomorphology and Natural Hazards. Geomorphology, 10, 1-18.

[3] Pimentel, D., Harvey, C., Resosudarmo, P., Sinclair, K., Kurz, D., McNairs, M., Crist, S., Shpritz, L., Fitton, L., Saffouri, R. and Blair, R. (1995) Environmental and Economic Costs of Soil Erosion and Conservation. Science, 267, 1117-1123. https://doi.org/10.1126/science.267.5201.1117

[4] Grecchi, R.C., Gwyn, Q.H.J., Bénié, G.B., Formaggio, A.R. and Fahl, F.C. (2014) Land Use and Land Cover changes in the Brazilian Cerrado: A Multidisciplinary Approach to Asses the Impacts of Agricultural Expansion. Applied Geography, 55, 300-312.

[5] Rada, N. (2013) AssessingBrazil's Cerrado AgriculturalMiracle. Food Policy, 28, 146-155.

[6] Tilman, D., Balzer, C., Hill, J. and Befort, B.L. (2011) Global Food Demand and the Sustainable Intensification of Agriculture. PNAS, 108, 20260-20264. https://doi.org/10.1073/pnas.1116437108

[7] Alexandratos, N. and Bruinsma, J. (2012) World Agriculture towards 2030/2050. The 2012 Revision. ESA Working Paper No. 12-03, FAO.

[8] Scherr, S.J. and Yadav, S. (1996) Land Degradation in the Developing World: Implications for Food, Agriculture, and the Environment to 2020. Food, Agriculture, and the Environment Discussion Paper 14, FAO.

[9] Wickramasinghe, U., Syed, S. and Siregar, H. (2012) The Role of Policies in Agricultural Transformation. Lessons from Brazil, Indonesia and the Republic of Korea. CAPSA Working Paper No. 106, CAPSA.

[10] Lahsen, M., Bustamante, M.M.C. and Dalla-Nora, E.L. (2016) Undervaluing and Overexploiting the Brazilian Cerrado at Our Peril. Environment. Science and Policy for Sustainable Development, 58, 4-15. https://doi.org/10.1080/00139157.2016.1229537

[11] IBGE (2010) Produção Agrícola municipal 2010. Instituto Brasileiro de Geografia e Estatística. https://sidra.ibge.gov.br/tabela/839

[12] The Economist (2010) The Miracle of Cerrado. Brazil Has Revolutionized Its Own Farms. Can It Do the Same for Others? http://www.economist.com/node/16886442

[13] Macedo, J. (1994) Solos dos Cerrados. In: Pereira, V.P., Ferreira, M.E. and Cruz, M.C.P., Eds., Solos altamente suscetíveis à erosão, FCAV-UNESP/SBCS, Jaboticabal, 69-75.

[14] OECD/Food and Agriculture Organization of the United Nations (2015) Brazilian Agriculture: Prospects and Challenges. In: OECD/Food and Agriculture Organization of the United Nations, OECD-FAO Agricultural Outlook 2015, OECD Publishing, Paris.

[15] Shi, Z.H., Cai, C.F., Ding, S.W., Wang, T.W. and Chow, T.L. (2004) Soil Conservation Planning at the Small Watershed Level Using RUSLE with GIS: A Case Study in 
the Three Gorge Area of China. Catena, 55, 33-48.

[16] Merritt, W.S., Letcher, R.A. and Jakeman, A.J. (2003) A Review of Erosion and Sediment Transport Models. Environmental Modelling \& Software, 18, 761-799.

[17] Wischmeier, W.H. and Smith, D.D. (1978) Predicting Rainfall Erosion Losses: A Guide to Conservation Planning. U.S. Department of Agriculture, Agriculture Handbook No. 537, USDA.

[18] Renard, K.G., Foster, G.R., Weesies, G.A., McCool, D.K. and Yoder, D.C. (1997) Predicting Soil Erosion by Water: A Guide to Conservation Planning with the Revised Universal Soil Loss Equation (RUSLE). U.S. Department of Agriculture, Agriculture Handbook No. 703, USDA.

[19] Zhang, H., Yang, Q., Li, R., Liu, Q., Moore, D., He, P., Ritsema, C.J. and Geissen, V. (2013) Extension of a GIS Procedure for Calculating the RUSLE Equation LS Factor. Computer \& Geoscience, 52, 177-188.

[20] Lu, D., Li, G., Valladares, G.S. and Batistella, M. (2004) Mapping Soil Erosion Risk in Rondônia, Brazilian Amazonia: Using RUSLE, Remote Sensing and GIS. Land Degradation \& Development, 15, 499-512. https://doi.org/10.1002/ldr.634

[21] Oliveira, P.T.S., Sobrinho, T.A., Rodrigues, D.B.B. and Panachuki, E. (2011) Erosion Risk Mapping Applied to Environmental Zoning. Water Resource Management, 25, 1021-1036. https://doi.org/10.1007/s11269-010-9739-0

[22] Beskow, S., Mello, C.R., Norton, L.D., Curi, N., Viola, M.R. and Avanzi, J.C. (2009) Soil Erosion Prediction in the Grande River Basin, Brazil Using Distributed Modelling. Catena, 79, 49-59.

[23] Parveen, R. and Kumar, U. (2012) Integrated Approach of Universal Soil Loss Equation (USLE) and Geographical Information System (GIS) for Soil Loss Risk Assessment in Upper South Koel Basin, Jharkhand. Journal of Geographic Information System, 4, 588-596. https://doi.org/10.4236/jgis.2012.46061

[24] Erdogan, E.H., Erpull, G. and Bayramin, I. (2007) Use of USLE/GIS Methodology for Prediction Soil Loss in a Semiarid Agriculture Watershed. Environmental Monitoring and Assessment, 131, 153-161. https://doi.org/10.1007/s10661-006-9464-6

[25] Farinasso, M., Carvalho Júnior, O.A., Guimarães, R.F., Gomes, R.A.T. and Ramos, V.M. (2006) Avaliação Quantitativa do Potencial de Erosão Laminar em Grandes Áreas por meio de EUPS-Equação Universal de Perdas de Solos Utilizando Novas Metodologias em SIG para os Cálculos dos seus Fatores na Região do Alto Parnaíba-PI-MA. Revista Brasileira de Morfologia, 7, 73-85.

[26] Trabaquini, K., Galvão, M.S.P., Formaggio, A.R. and Galvão, L.S. (2012) Estimates of Land Use and Land Cover Change and Soil Loss in the Brazilian Cerrado through Geotecnology. IGARSS Proceedings of IEEE International Geoscience and Remote Sensing Symposium. Remote Sensing for a Dynamic Earth, Munich, 6321-6324.

[27] Lewinsohn, T.M. and Prado, P.I. (2005) How Many Species Are There in Brazil? Conservation Biology, 19, 619-624. https://doi.org/10.1111/j.1523-1739.2005.00680.x

[28] Eiten, G. (1972) The Cerrado Vegetation of Brazil. Botanical Review, 38, 201-341. https://doi.org/10.1007/BF02859158

[29] Bustamante, M.M.C., Nardoto, G.B., Pinto, A.S., Resende, J.C.F., Takahashi, F.S.C. and Vieira, L.C.G. (2012) Potential Impacts of Climate Change on Biogeochemical Functioning of Cerrado Ecosystems. Brazilian Journal of Biology, 72, 655-671. https://doi.org/10.1590/s1519-69842012000400005

[30] Santos, H.G., Carvalho Júnior, W., Dart, R.O., Áglio, M.L.D., Sousa, J.S., Pares, J.G., Fontana, A., Martins, A.L.S. and Oliveira, A.P. (2011) O Novo Mapas de Solos do 
Brasil. Legenda Atualizada-Dados Eletrônicos. EMBRAPA Solos, 67 p.

[31] Food and Agriculture Organization (FAO) (1974) Soil Map of the World: 1:5.000.000 Legend. UNESCO, 1.

[32] Valeriano, M.M. (2008) TOPODATA: Guia de utilização de dados geomorfométricos locais. Instituto Nacional de Pesquisas Espaciais, Relatório Técnico (INPE-15318-RPQ/818).

[33] Ribeiro, J.F. and Walter, B.M.T. (1998) Fitofisionomias do Bioma Cerrado. In: Sano, S.M. andAmeida, S.P., Eds., Cerrado Ambiente e Flora, Embrapa Cerrados, Planaltina, 89-166.

[34] Mittermeier, R.A., Gil, P.R., Hoffman, M., Pilgrim, J., Brooks, T., Mittermeier, C.G., Lamoreux, J. and Fonseca, G.A.B. (2005) Hotspot Revisited: Earth's Biologically Richest and Most Endangered Terrestrial Ecoregions. 2th Edition, University of Chicago Press, Boston.

[35] Dias, L.C.P., Pimenta, F.M., Santos, A.B., Costa, M.H. and Ladle, R.J. (2016) Patterns of Land Use, Extensification, and Intensification of Brazilian Agriculture. Global Change Biology, 1-16.

[36] Oliveira, P.T.S., Wendland, E. and Nearing, M.A. (2012) Rainfall Erosivity in Brazil: A Review. Catena, 100, 139-147.

[37] IBGE (2015) Mapa de Uso e Cobertura da Terra de 2010. Instituto Brasileiro de Geografia e Estatística.

[38] CONAB (2011) Acompanhamento da Safra Brasileira: Grãos-Safra 2010/2011. Companhia Nacional de Abastecimento, Brasília.

[39] Rudorff, B.F.T., Aguiar, D.A., Silva, W.F., Sugawara, L.M., Adami, M. and Moreira, M.A. (2010) Studies on the Rapid Expansion of Sugarcane for Ethanol Production in São Paulo State (Brazil) Using Landsat Data. Remote Sensing, 2, 1057-1076. https://doi.org/10.3390/rs2041057

[40] Moreira, M.A., Rudorff, B.F.T., Barros, M.A., de Faria, V.G.C. and Adami, M.A. (2010) Geotecnologias para mapear lavouras de café nos Estados de Minas Gerais e São Paulo. Engenharia Agricola, 30, 1123-1135. https://doi.org/10.1590/S0100-69162010000600013

[41] Zhang, L., O’Neill, A. and Lacy, S. (1995) Spatial Analysis of Soil Erosion in Catchments: A Review of Modelling Approaches. Water Resources and Ecology, 3, 58-64.

[42] Kinnel, P.I.A. (2010) Event Soil Loss, Runoff and the Universal Soil Loss Equation Family of Models: A Review. Journal of Hydrology, 385, 384-397.

[43] Wischmeier, W.H. and Mannering, J.V. (1969) Soil and Water Management and Conservation. Relation of Soil Properties to Its Erodibility. Soil Science Society of America, Proceedings, 33, 131-137. https://doi.org/10.2136/sssaj1969.03615995003300010035x

[44] Farhan Y. and Nawaiseh, S. (2015) Spatial Assessment of Soil Erosion Risk Using RUSLE and GIS Techniques. Environmental Earth Sciences, 74, 4649-4669. https://doi.org/10.1007/s12665-015-4430-7

[45] Demarchi, J.C. andZimback, C.R.L. (2014) Mapeamento, Erodibilidade e Tolerância de Perda de Solo na Sub-bacia do Ribeirão das Perobas. Energia na Agricultura, 29, 102-114. https://doi.org/10.17224/EnergAgric.2014v29n2p102-114

[46] Mannigel, A.R., Carvalho, M.P., Moreti, D. and Luciano, R.M. (2002) Fator Erodibilidade e Tolerância de Perda de Solos do Estado de São Paulo. Acta Scientiarum, 24, 1335-1340. https://doi.org/10.4025/actasciagron.v24i0.2374

[47] Cabral, J.B.P., Becegato, V.A., Scopel, I. and Lopes, R.M. (2005) Uso de Técnicas de Geoprocessamento para Mapear o Potencial Natural de Erosão da Chuva na Bacia 
Hidrográfica do Reservatório de Cachoeira Dourada-GO/MG. RevistaRa'EGa, 10, 107-116. https://doi.org/10.5380/raega.v10i0.4982

[48] Castro, W.J., Lemke-de-Castro, M.L., Lima, J.O., Oliveira, L.F.C., Rodrigues, C. and Figueiredo, C.C. (2011) Erodibilidade de Solos do Cerrado Goiano. Revista em Agronegócios e Meio Ambiente, 4, 305-320.

[49] Da Silva, A.M., Silva, M.L.N., Curi, N., Avanzi, J.C. and Ferreira, M.M. (2009) Erosividade da Chuva e Erodibilidade de Cambissolo e Latossolo na Região de Lavras, Sul de Minas Gerais. Revista Brasileira de Ciência do Solo, 33, 1811-1820. https://doi.org/10.1590/S0100-06832009000600029

[50] Da Silva, A.M. and Alvares, C.A. (2005) Levantamento de Informações e Estruturação de um Banco de Dados sobre a Erodibilidade de Classes de Solos no Estado de São Paulo. Geociências, 24, 33-41.

[51] Ahmad, N. and Mermut, A. (1996) Vertisols and Technologies for Their Management. Elsevier, Amsterdam, 152.

[52] Brooks, K.N., Ffolliott, P.F., Gregersen, H.M. and DeBano, L.F. (2003) Hydrology and the Management of Watershed. Blackwell Publishing, Ames, 825.

[53] Desmet, P.J.J. and Govers, G. (1996) A GIS Procedure for Automatically Calculating the USLE LS Factor on Topographically Complex Landscape Units. Journal of Soil and Water Conservation, 51, 427-433.

[54] McCool, D.K., Brown, G.R., Foster, G.R. and Meyer, L.D. (1987) Revised Slope Steepness Factor for the Universal Soil Loss Equation. American Society of Agricultural Engineers, 30, 1387-1396. https://doi.org/10.13031/2013.30576

[55] Ramalho Filho, A. And Beek, K.J. (1995) Sistema de Avaliação da Aptidão Agrícola das Terras. 3th Edition, EMBRAPA-CNPS, Rio de Janeiro.

[56] Gasnari, B.P. and Ramesh, H. (2016) Assessment of Soil Erosion by RUSLE Model Using Remote Sensing and GIS-A Case Study of Nethravathi Basin. Geoscience Frontiers, 7, 953-961.

[57] Galdino, S. (2012) Estimativa da Perda de Terra sob Pastagens Cultivadas em Solos Arenosos da Bacia Hidrográfica do Alto Taquari-MS/MT. PhD Thesis, Universidade Estadual de Campinas, Campinas.

[58] Peron, A.J. and Evangelista, A.R. (2003) Degradação de Pastagens em Regiões de Cerrado. Ciência e Agrotecnologia, 28, 655-661. https://doi.org/10.1590/S1413-70542004000300023

[59] Oliveira, P.T.S., Nearing, M.A. and Wendland, E. (2015) Orders of Magnitude Increase in Soil Erosion Associated with Land Use Change from Native to Cultivated Vegetation in a Brazilian Savannah Environment. Earth Surface Processes and Landforms, 40, 1524-1532. https://doi.org/10.1002/esp.3738

[60] Martins, S.G., Silva, M.L.N., Avanzi, J.C., Curi, N. and Fonseca, S. (2010) CoverManagement Factor and Soil and Water Losses from Eucalyptus Cultivation and Atlantic Forest at the Coastal Palin in the Espírito Santo State, Brazil. Scientia Forestalis, 38, 517-526.

[61] Bertol, I., Schick, J. and Batistela, O. (2001) Razão de Perdas de Solo e Fator C para as Culturas de Soja e Trigo em três Sistemas de Preparo em um Cambissolo Húmico Alumínico. Revista Brasileira de Ciência do Solo, 25, 451-461. https://doi.org/10.1590/S0100-06832001000200021

[62] Weill, M.A.M. (1999) Estimativa da Erosão do Solo e Avaliação do seu Impacto na Microbacia do Ceveiro (Piracicaba, SP) através do Índice de Tempo de Vida. PhD Thesis, Universidade de São Paulo, Piracicaba.

[63] Prochnow, D., Dechen, S.C.F., de Maria, I.C., Castro, O.M. and Vieira, S.R. (2005) 
Razão de Perdas de Terra e Fator C da Cultura do Cafeeiro em Cinco Espaçamentos, em Pindorama (SP). Revista Brasileira de Ciência do Solo, 29, 91-98. https://doi.org/10.1590/S0100-06832005000100010

[64] Pandey, A., Chowdary, V.M. and Mal, B.C. (2007) Identification of Critical Erosion Prone Areas in the Small Agricultural Watershed Using USLE, GIS and Remote Sensing. Water Resource Management, 21, 729-746. https://doi.org/10.1007/s11269-006-9061-Z

[65] Oliveira, A.M.M.D., Pinto, S.D.A.F. and Lombardi Neto, F. (2007) Caracterização de Indicadores de Erosão do Solo em Bacias Hidrográficas com Suporte de Geotecnologias e Modelo Preditivo. Revue Geographique De P Est, 5, 63-86.

[66] IBGE (2006) Censo Agropecuário 2006. Instituto Brasileiro de Geografia e Estatística.

[67] Castro, A.G. and Valério Filho, M. (1997) Simulação da Expectativa de Perda de Solo em Microbacias sobre Diferentes Manejos Florestais. Revista Brasileira de Ciência do Solo, 21, 419-426. https://doi.org/10.1590/S0100-06831997000300010

[68] Freitas, P.L and Landers, J.N. (2014) The Transformation of Agriculture in Brazil through Development and Adoption of Zero Tillage Conservation Agriculture. International Soil and Water Conservation Research, 2, 35-46.

[69] Food and Agriculture Organization (FAO) (1967) La erosióndelsuelopor el áqua. Algunas medidas para combartilaenlastierras de cultivo. Cuadernos de Fomento Agropecuário da Organizácion de LasNaciones Unidas, 81, 207 p.

[70] Ayer, J.E.B., Olivetti, D., Mincato, R.L. and Silva, M.L.N. (2015) Erosão Hídrica em Latossolos vermelhos distróficos. Pesquisa Agropecuária Tropical, 45, 180-191. https://doi.org/10.1590/1983-40632015v4531197

[71] Sparovek, G. and Schnug, E. (2001) Temporal Erosion-Induced Soil Degradation and Yield Loss. Soil Science Society of America Journal, 65, 1479-1486. https://doi.org/10.2136/sssaj2001.6551479x

[72] Amorim, R.S.S., da Silva, D.D., Pruski, F.F. and de Matos, A.T. (2010) Avaliação de Desempenho dos Modelos de Predição da Erosão Hídrica USLE, RUSLE e Wepp para Diferentes Condições Edafoclimáticas do Brasil. Engenharia Agrícola, 30, 1046-1049. https://doi.org/10.1590/s0100-69162010000600006

[73] MMA (2011) Monitoramento do Desatamento nos Biomas Brasileiros por Satélite. Acordo de Cooperação Técnica MMA/IBAMA. Monitoramento do Bioma Cerrado 2009-2010. Ministério do Meio Ambiente. 
Submit or recommend next manuscript to SCIRP and we will provide best service for you:

Accepting pre-submission inquiries through Email, Facebook, LinkedIn, Twitter, etc. A wide selection of journals (inclusive of 9 subjects, more than 200 journals)

Providing 24-hour high-quality service

User-friendly online submission system

Fair and swift peer-review system

Efficient typesetting and proofreading procedure

Display of the result of downloads and visits, as well as the number of cited articles Maximum dissemination of your research work

Submit your manuscript at: http://papersubmission.scirp.org/

Or contact jgis@scirp.org 